\title{
Nowe media w procesie kształtowania tożsamości
}

Łukasz Kamiński | Wydział Nauk Społecznych, Uniwersytet Gdański

Słowa kluczowe:

tożsamość, młodzież, dorośli nowe media, portal społecznościowy identity, youth, adults, new media, social network

\section{Streszczenie}

Celem niniejszego artykułu jest ukazanie problemu, jakim jest nadmierny wpływ nowych mediów na młodych ludzi, którzy korzystają z nich coraz chętniej. Dzieciństwo to najważniejszy okres w kontekście kształtowania tożsamości. Brak autorytetów w życiu realnym, przeniesienie całej swojej uwagi na to, co dzieje się w Internecie, niesie za sobą wielkie zagrożenie. Znacznemu pogorszeniu może ulec jakość kontaktów z rówieśnikami. Nadmierna fascynacja światem portali społecznościowych i całkowite poświęcenie uwagi temu, co się w nich dzieje to już dziś poważny kłopot wielu młodych ludzi. W tej sytuacji rola osób dorosłych z ich najbliższego otoczenia wydaje się nieoceniona, i to zadaniem dorosłych jest zapewnienie młodszym pokoleniom możliwości równie atrakcyjnych jak te $w$ świecie online.

\section{New media in the shaping of identity process}

\section{Summary}

The aim of this paper is to present the problem, that is excessive influence of new media on young people, who use the media more and more willingly. The childhood is the most important period in shaping of our identity. Lack of authorities in the real life and moving the attention to the Internet is a great threat for young people. Addiction to mobile phones and the Internet can cause problems with relations with their equals and the adults. Excessive fascination with the world of social media and total attention to what is happening in them is a serious problem for many young people today. In this case, the role of adults seems invaluable, because it is in their hands to provide younger generations with alternatives as attractive as those in the online world. 


\section{Wstęp}

Niniejszy artykuł ma na celu zwrócenie uwagi na coraz częstszy w dzisiejszych czasach problem niezdrowej fascynacji młodych ludzi światem online, w szczególności światem portali społecznościowych, które są przedstawicielem szeroko pojętych nowych mediów. Młodzież jest podatna na różnego rodzaju wpływy, dlatego zagrożenie, jakie niosą z sobą nowe media, jest ogromne. Problem jest tym większy, że to przecież w tym właśnie okresie kształtuje się tożsamość, a więc będzie on miał realny wpływ na przyszłość młodzieży, a co za tym idzie - przyszłość kolejnych pokoleń. To sprawia, że osoby dorosłe stają dzisiaj przed niezwykle ważnym zadaniem: znalezieniem sposobu, jak odciągnąć młodych sprzed ekranu smartfona.

\section{Tożsamość i jej kształtowanie}

Tożsamość - „identyczność”, „świadomość siebie”, „fakty, cechy, dane personalne pozwalające zidentyfikować jakąś osobę”, wreszcie „świadomość wspólnych cech i poczucie jedności". Katarzyna Skrzypczak pisze, że słowo to ma długą historię, ale do nauk społecznych i dyskursu publicznego zostało wprowadzone dopiero w latach sześćdziesiątych XX wieku w Stanach Zjednoczonych. Tożsamość jest rozpatrywana jako zjawisko zbiorowe, które odwołuje się do podobieństwa członków danej grupy. Bywa również pojmowana jako fundamentalna jakość bytu społecznego, która określa coś pierwotnego i stałego, a także produkt aktywności społecznej lub politycznej, gdzie wyróżnia się takie elementy, jak wzajemne zrozumienie w grupie, przynależność do tej grupy i solidarność w jej obrębie (Skrzypczak 2010: 204-205). Ustalenie tożsamości to $w$ takim razie rozpoznanie specyficznych cech, którymi różni się dana osoba lub grupa od pozostałych, czyli samowiedza składająca się z cech postrzeganych przez podmiot jako najbardziej charakterystyczne dla własnej osoby oraz jednocześnie najbardziej specyficzne, czyli te najmocniej odróżniające od innych ludzi (Wojciszke 2006: 140).

Ścisły związek z kształtowaniem tożsamości ma socjalizacja, czyli wrastanie dziecka w kulturę; to w dużym stopniu nabywanie wartości (dziecko uczy się cenić pewne wartości, np. odpowiedzialność czy uczciwość) oraz wykształcanie pewnych postaw (uczy się lubić szpinak) (Wojciszke 2006: 178). Socjalizacja jest procesem nabywania tożsamości i wartości, przekonań i postaw oraz reguł przeżywania świata i zachowania, dzięki którym jednostka może skutecznie funkcjonować jako członek danego społeczeństwa (Wojciszke 2006: 442). Aneta Skuza pisze z kolei, że człowiek rodzi się jako istota biologiczna, a istotą społeczną staje się dopiero pod wpływem kultury tegoż społeczeństwa. Istniejące wzorce kształtują człowieka już od pierwszej chwili po urodzeniu. Kultura jest czymś zewnętrznym, czymś, czego człowiek musi się dopiero nauczyć (Skuza 2011:225). Ta sama autorka dodaje, że socjalizacja trwa przez całe życie, ponieważ społeczeństwo nieustannie dostarcza człowiekowi bodźców do kształtowania poglądów i zachowań (Skuza 2011: 230). 


\section{Nowe media w życiu Polaków}

Jak pokazują badania przeprowadzone przez Centrum Badania Opinii Społecznej (2017), w 2017 r. 67\% dorosłych Polaków regularnie (przynajmniej raz w tygodniu) korzystało z Internetu, a praktycznie wszyscy badani w wieku 18-24 deklarowali swoją obecność w Internecie. Wśród ankietowanych w wieku 25-34 lata ta liczba jest nieznacznie mniejsza i wynosi $96 \%$. Średni czas spędzany online to prawie 12 godzin, ale młodzi (18-24) śrubują ten wynik do ponad 20 godzin. Ta sama grupa wiekowa przoduje również jeśli chodzi o liczbę internautów zarejestrowanych na portalach społecznościowych (94\%). Główny Urząd Statystyczny (2016) zapytał z kolei opiekunów dzieci w wieku 5-15 lat o korzystanie z technologii informacyjno-telekomunikacyjnych przez ich dzieci. Okazało się, że ponad $90 \%$ opiekunów pozwala korzystać dzieciom z komputera. Co czwarty z nich pozwala używać konsoli do gier. W porównaniu z rokiem 2013 wskaźnik gospodarstw domowych, w których dzieci korzystały ze smartfonów, wzrósł w roku 2016 o 31\% i wyniósł 44,1\%. 3 lata - 31\%! To dosadnie pokazuje tendencję..,Jeżeli twoje dziecko nie śpi, to prawdopodobnie jest online” (Fliciak i in. 2010: 4).

Nowe media dają ludziom wielkie możliwości. Czym jednak są naprawdę? Jacek Pyżalski uważa, że mogą być one rozpatrywane jako zjawisko biologiczno-fizyczne (mowa), środki służące porozumiewaniu się (papier, komputer), instytucje, w których pracują osoby zajmujące się komunikacją, produkty wytworzone przez te instytucje, lub nawet jako cały konglomerat procesów społecznych związanych z komunikacją medialną (Pyżalski 2012: 14-16). W Raporcie Centrum Badań nad Kulturą Popularną możemy przeczytać, że termin „nowe media” jest względny, gdyż każde medium było kiedyś nowe. Autorzy raportu przyjmują jednak, że określenie „nowe media” stosują do Internetu, telefonów komórkowych i cyfrowych aparatów fotograficznych (Fliciak i in. 2010: 6).

Firmy wiedzą, że siła oddziaływania Internetu jest tak wielka, że jakiekolwiek faux pas pracownika nawet na najniższym szczeblu może przynieść straty wizerunkowe dla całej organizacji. Dlatego firmy, i te wielkie, i te mniejsze, dbają o swój wizerunek w mediach społecznościowych (według badań GUS 67\% przedsiębiorstw posiada własną stronę internetową, a 25,3\% korzysta z portali społecznościowych, z tym że wśród dużych przedsiębiorstw liczba ta wzrasta do 54,4\%), zdając sobie sprawę z siły, jaką posiada dziś każdy użytkownik tych mediów. Wszystko w tej materii pozostaje kwestią wyboru. Można bowiem ulegać wpływom, albo rozsądnie się przed nimi bronić i filtrować wszystkie treści, które docierają z Internetu.

\section{Rodzina to podstawa}

Możliwości wyboru. W pewnym wieku można szukać ich samemu, ale do pewnego wieku należy je po prostu otrzymywać. Jak najwięcej. Młodzi ludzie, bo o nich mowa, potrzebują w tej kwestii wiele wsparcia - drogowskazów, które pomogą im odnaleźć 
się pośród szalonego świata XXI wieku. Tożsamość kształtowana jest całe życie, ale najbardziej podatnym na wpływy, chłonnym i otwartym na nowe idee jest się w wieku młodzieńczym. Anna Brzezińska (2006: 7) pisze, że tożsamość kształtuje się w ciągu całego życia, ale najważniejszymi okresami są dzieciństwo i dorastanie. W dzieciństwie człowiek gromadzi wiedzę o świecie i o sobie samym, podczas gdy okres dorastania to czas rozwijania się, poczucia identyczności, ciągłości i integralności. Pisząc o najbliższym otoczeniu, należy w pierwszej kolejności wspomnieć o rodzinie. Bo przecież rodzina to centralny, najważniejszy układ odniesienia w każdej grupie kulturowej. To tam tworzy się tożsamość kulturowa jednostki. Rodzice przekazują dziecku język, system wartości, panujące obyczaje (Paleczny 2008: 85). Joanna Juszczyk wspomina o edukacji tożsamościowej, która może odbywać się w sposób jawny i ukryty. Edukacja jawna to intencjonalne wywieranie wpływu oparte na przyjętych wzorcach, ukryta zaś - to przekazywanie wzorców oficjalnie niepożądanych, ale występujących w rzeczywistości społecznej. Powinna ona odbywać w przestrzeni rodzinnej, bo to właśnie rodzina jest pierwszym tożsamościowym edukatorem dziecka, stanowi jego podstawowe i pierwotne środowisko wychowawcze (Juszczyk-Rygałło 2016: 23).

Anna Brzezińska (2006: 26) podkreśla rolę najbliższych w procesie kształtowania się świadomości młodych ludzi. Nazywa ich „czynnikiem kluczowym”. Opisuje ich jako wzór do naśladowania, obiekt identyfikacji i autorytet moralny. Źródło informacji o świecie, wsparcie i pomoc. Jako starsze pokolenie widzi w nich strażników tradycji. Nazywa ich pośrednikami pomiędzy pokoleniami, które dorastały w różnych czasach.

\section{Niebezpieczny Internet}

Życie w wirtualnym świecie jest dla młodych atrakcyjniejsze, to już „nie media muszą zabiegać teraz o wierność przedstawianym realiom życiowym; to realia życiowe muszą upodabniać się do wizji medialnych i starać się jak mogą dorównać ich cnotom. Zaprzestać starań mogą tylko na własną zgubę" (Fliciak i in. 2010: 131). Nie ma ich na boisku piłkarskim - w piłkę nie grają, bo mają FIFĘ, każdego roku nowszą. Na trzepak (legendarny!) czy ławkę już nie chodzą, bo mają grupy na FB. Nie rozmawiają - komunikują się. Nie spacerują - grają w SIMS. Koncerty? Jest YouTube. Kontakt z rówieśnikiem - wstawiają zdjęcie na Instagram. Problem? Mało lajków. Kłótnia? - jak ktoś nie oznaczy w poście. Związki są facebookowe - dokładnie datowane, opisane, opatrzone milionem fotografii. „Kilka lat wstecz dało się zauważyć duże grupy dzieci i młodzieży przesiadujących na ławkach przed blokiem czy też uprawiających sport na osiedlowych boiskach. Dzisiaj taki widok to rzadkość" (Kozak 2013: 169).

Sytuacja stała się na tyle poważna, że mówi się już o uzależnieniu od telefonu (fonoholizm), a także w dalszej kolejności od Internetu. Fonoholizm zaliczany jest do uzależnień od popędów i czynności. Stanisław Kozak opisuje go jako poddanie się człowieka uzależnionego czynności nałogowej, wokół której skupia on swoje myśli i która zajmuje w jego życiu coraz więcej miejsca. Do tego stopnia, że traci on nad nim kontrolę. 
Czynność ta w uzależnieniu przestaje pełnić właściwą sobie funkcję (telefon dla człowieka), a staje się celem samym w sobie (człowiek dla telefonu). Mimo ewidentnych szkód, które są następstwem nałogu, człowiek uzależniony nie potrafi z nim zerwać (Kozak 2013: 78).

Oprócz zjawiska fonoholizmu autor wskazuje również na istnienie innego problemu, jakim jest uzależnienie od Internetu, czyli internetoholizm. W obowiązujących w Polsce kryteriach diagnostycznych Światowej Organizacji Zdrowia nie zdiagnozowano zjawiska siecioholizmu, lecz psychologowie, którzy w nadmiernym korzystaniu z Internetu widzą poważny problem, twierdzą, że jest on porównywalny nawet z alkoholizmem, narkomanią czy skłonnościami do hazardu (Kozak 2013: 81). Związ$\mathrm{ki}_{\text {, }}$ realne" - z rodziną, partnerem, znajomymi - ulegają degeneracji z powodu nowej, sieciowej tożsamości. Autor stwierdza, że czas spędzany przez osobę uzależnioną od Internetu przed komputerem zwykle zaburza stosunki rodzinne. Osoby, które spędzają tak ponad cztery i pół godziny dziennie, odczuwają dyskomfort, próbując ten czas ograniczyć. Próba ograniczenia dostępu do poczty elektronicznej to wręcz katastrofa. Brak kontaktu z komputerem to „brak możliwości oddychania” (Kozak 2013: 85).

A to właśnie nic innego jak liczne kontakty społeczne (rodzinne, koleżeńskie, sąsiedzkie) uważa Brzezińska (2006: 26) za warunek konieczny do tego, aby proces kształtowania tożsamości przebiegał poprawnie. Uczestnictwo w wolontariacie, akcjach społecznych (np. WOŚP), włączanie się do realizacji różnych zadań (w szkole, miejscu zamieszkania) czy spotkania towarzyskie (mecze, koncerty) z rówieśnikami, a także z młodszymi i starszymi sprzyjają rozpoznawaniu własnych zasobów, a także zasobów otaczającego świata. Młody człowiek dowiaduje się wiele o jakości relacji, jakie łączą go z innymi ludźmi, a także może zajrzeć w głąb siebie i odnaleźć odpowiedź na nurtujące pytania: co umiem? Co wiem? Co robię najlepiej w grupie? Co jest moją słabością? A tymczasem, jak w jednym z wywiadów mówi Mirosława Marody:

Obserwując zalew autofotografii i w internecie, dochodzę czasami do wniosku, że erupcję tego swoistego narcyzmu tłumaczyć można tylko jednym - poszukiwaniem dowodu na własne istnienie. Oto jestem, wydają się wołać ich autorzy, dostrzeżcie mnie proszę, zwróćcie uwagę, jaki/a jestem zabawny/a, przystojny/a, wysportowany/a, wyluzowany/a (Fliciak i in. 2010: 68).

Granica między działaniem a wyrażaniem zaciera się, bo zdjęcia stanowią dla młodych integralną część przeżywanego świata. Podobnie zaciera się granica między wydarzeniem a jego cyfrową reprezentacją (Fliciak i in. 2010: 41).,,Wiedza o sobie jest podstawowym wyznacznikiem poczucia własnej tożsamości" pisze Wojciszke (2006: 141). Młodzi są zagubieni i szukają tej wiedzy. 


\section{Media społecznościowe rządzą}

Portal społecznościowy to serwis internetowy funkcjonujący na podstawie społeczności, która się wokół niego gromadzi (Kozak 2013: 169). Portal jest nastawiony na interakcję między jego użytkownikami. Przepływ informacji, w przeciwieństwie do tradycyjnych portali, odbywa się według modelu użytkownik - użytkownik (w tradycyjnym ujęciu jest to model twórca portalu - użytkownik). Istotną cechą portalu społecznościowego jest fakt, że użytkownicy są jednocześnie jego współtwórcami, portal funkcjonuje więc dzięki ich aktywności. Służą do komunikowania się, umożliwiają przepływ informacji, pozwalają na publikowanie zdjęć, filmów oraz tekstów. Ważną częścią każdego serwisu społecznościowego jest profil użytkownika, który zawiera opis jego zainteresowań i poglądów. W połowie lat dziewięćdziesiątych w Stanach Zjednoczonych zanotowano pojawienie się pierwszych portali społecznościowych (Grześkowiak, 2011:359-360). Oficjalne statystyki najpopularniejszego tego typu serwisu - Facebooka - podają, że w marcu 2018 r. codziennie korzystało z niego średnio 1,45 mld osób, a ogólnie portal liczy sobie 2,20 mld aktywnych użytkowników miesięcznie na dzień 31 marca 2018. Liczby te robią wrażenie. Z całą pewnością Facebook stwarza użytkownikom wiele możliwości i korzystanie z niego ma wiele pozytywnych aspektów, jednak pamiętać należy o niebezpieczeństwach wynikających ze zbytniej fascynacji jakimś obiektem. A mamy z czymś takim do czynienia jeśli chodzi o Facebooka. Pisze o tym np. Kozak:

Wiele osób nie zauważa, jak w krótkim okresie Facebook staje się głównym elementem ich życia. Nie wyobrażają sobie dnia bez skorzystania ze strony. Coraz więcej czasu spędzają w przestrzeni wirtualnej niż w rzeczywistości (Kozak 2013: 172).

Innym popularnym portalem jest Instagram. A tam wśród czołowej trzydziestki trzykrotnie przewija się nazwisko Kardashian, które ciężko jest jednoznacznie przypisać do konkretnej kategorii: sportowiec, artysta, polityk. Po prostu gwiazda. Czołówka kont facebookowych to lista najpopularniejszych koncernów, które dają światu m.in. napój o tajemniczej wciąż recepturze i najszybsze hamburgery na świecie, piłkarskie kluby i Jaś Fasola. Bardzo podobnie wygląda sprawa z kontami na portalu Twitter. Nazwiska i instytucje się powtarzają, uwagę przykuwa trzecie miejsce Baracka Obamy. Szesnaste miejsce mają wiadomości CNN, a dwudzieste obecny prezydent najpotężniejszego państwa świata. Historia pamięta wiele osób, które na jej kartach zapisały się złotymi zgłoskami i które decydowały o losach świata. Byli politykami, wybitnymi wodzami, filozofami, poetami, fizykami, geniuszami muzycznymi. Dziś ideałem jest piłkarz z Portugalii, który twierdzi, że wszyscy mu zazdroszczą, bo jest przystojny i świetnie gra w piłkę, albo piosenkarka, która zaistniała hitem o parasolu. Należy szanować ich dorobek, gdyż został wypracowany determinacją i poświęceniem, ale jeśli to oni będą stanowić wzór kobiety i mężczyzny, jeśli to oni zakotwiczą w głowach młodych ludzi jako ideał, do którego ci będą chcieli dążyć, to wtedy pojawi się problem. 


\section{Zakończenie}

Każda rzecz stworzona, by uprzyjemnić życie, a nieodpowiednio nadużyta, staje się groźną bronią. Tak jest z Facebookiem, Instagramem i dziesiątkami innych, nowoczesnych mediów. Z jednej strony są wspaniałym narzędziem ułatwiającym zarówno pracę, jak i kontakty z ludźmi, z drugiej zaś, w zastraszającym tempie stają się sensem życia wielu młodych osób, które przenoszą swoje zainteresowanie z tego, co otacza je w świecie rzeczywistym, na to, co mogą spotkać online. Taka tendencja trwa już od kilku lat, a jak pokazują statystyki - ciągle rośnie. Uniemożliwienie młodzieży korzystania z najnowocześniejszej technologii wydaje się niemożliwe, a dodatkowo nie byłoby zbyt wychowawcze. Taka sytuacja stawia osoby dorosłe w obliczu poważnego wyzwania, na ich barkach bowiem spoczywa ciężar odpowiedzialności za tych, którzy w dorosłość dopiero wchodzą.

\section{Bibliografia}

Brzezińska, A., 2006, Dzieciństwo i dorastanie: korzenie tożsamości osobistej i społecznej [w:] A. Brzezińska, A. Hulewska, J. Słomska (red.), Edukacja regionalna. Wybór tekstów, Warszawa:, http://scholar.googleusercontent.com/scholarq=cache:piSkO9mvjWQJ:scholar.google.com/\&hl=pl\&as_sdt=0,5 [dostęp: 15.04.2018].

Centrum Badania Opinii Społecznej, Korzystanie z Internetu, Komunikat z Badań, Nr 49/2017.

Fliciak M., Danielewicz M., Halawa M., Mazurek P., Nowotny A., 2010, Młodzi i media: Nowe media uczestniczq w kulturze, Warszawa: Szkoła Wyższa Psychologii Społecznej

Główny Urząd Statystyczny , "Społeczeństwo informacyjne w Polsce 2016”, Opracowanie sygnalne, 20.10.2016, Warszawa, https://stat.gov.pl/obszary-tematyczne/nauka-i-technika-spoleczenstwo-informacyjne/spoleczenstwo-informacyjne/spoleczenstwo-informacyjne-w-polsce-w-2016-roku,2,6. html [dostęp: 16.04.2018].

Grześkowiak U.M., 2011, Portale społecznościowe - wybrane aspekty, "Zeszyty Naukowe Uniwersytetu Szczecińskiego", nr 656, http://www.wneiz.pl/studiainformatica/studia-informatica-numery/ studia-informatica-28-2011/1495-portale-spolecznosciowe-wybrane-aspekty [dostęp: 17.05.2018]. https://newsroom.fb.com/company-info/ [dostęp: 17.05.2018].

Juszczyk-Rygałło J., 2016, Socjalizacja dziecka jako proces kształtowania tożsamości, „Edukacja Elementarna w Teorii i Praktyce", t. 11, nr 4.

Kozak S., 2013, Patologia fonoholizmu. Przyczyny, skutki i leczenie uzależnienia dzieci i młodzieży od telefonu komórkowego, Warszawa: Difin.

Mazurek P., 2006, Internet a tożsamość [w:] D. Batorski, M. Marody, A. Nowak (red.), Społeczna przestrzeń internetu, Warszawa, http://www.academia.edu/2042363/Mazurek_Pawe\%C5\%82_2006_ Internet_a_to\%C5\%BCsamo\%C5\%9B\%C4\%87_w_D._Batorski_M._Marody_A._Nowak_red._ Spo\%C5\%82eczna_przestrze\%C5\%84_internetu_Warszawa_Wyd._SWPS [dostęp: 11.04.2018].

Paleczny T., 2008, Socjologia tożsamości, Kraków: Oficyna Wydawnicza AFM.

Pyżalski J., 2012, Agresja elektroniczna i cyberbullying jako nowe ryzykowne zachowanie młodzieży, Kraków: Impuls. 
Skrzypczak A., 2010, Jaka tożsamość kulturowa dla dzisiejszej Europy?, „Refleksje”, wiosna - lato, nr 1, Wydawnictwo Naukowe WNPiD UAM, https://issuu.com/filipbiay/docs/refleksje-nr1 [dostęp: 9.04.2018].

Skuza A., 2012, Interakcje społeczne w procesie socjalizacji, „Forum Pedagogiczne”, nr 1.

Słownik Języka Polskiego PWN, https://sjp.pwn.pl/sjp/to\%C5\%BCsamo\%C5\%9B\%C4\%87;2530211 [dostęp: 16.04.2018].

Wojciszke B., 2006, Człowiek wśród ludzi. Zarys psychologii społecznej, Warszawa: Scholar.

Wrońska M., 2013, Dorastanie w środowisku cyfrowym - od immersji, poprzez bezkrytyczna fascynację, do kultury medialnej, Katedra Technologii i Mediów Edukacyjnych. Uniwersytet Pedagogiczny, http://scholar.google.pl/citations?user=epgj4k0AAAAJ\&hl=pl [dostęp: 8.04.2008]. 